\title{
Original Article \\ Phytochemical Composition and Antioxidant Capacity of Three Malian Medicinal Plant Parts
}

\author{
François Muanda, ${ }^{1}$ Donatien Koné, ${ }^{1}$ Amadou Dicko, ${ }^{1}$ Rachid Soulimani, ${ }^{2}$ \\ and Chafique Younos ${ }^{2}$ \\ ${ }^{1}$ Chemistry Laboratory and Methodologies for the Environment, Paul-Verlaine University, 57078 Metz, France \\ ${ }^{2}$ Ethnobotanic, Pharmacology, Anxiety, Stress Oxidative and Bioactivity Laboratory, University P. Verlaine-Metz, Metz, France
}

Correspondence should be addressed to Amadou Dicko, dicko@univ-metz.fr

Received 17 October 2008; Accepted 22 July 2009

Copyright (C) 2011 François Muanda et al. This is an open access article distributed under the Creative Commons Attribution License, which permits unrestricted use, distribution, and reproduction in any medium, provided the original work is properly cited.

This study evaluates the levels of total polyphenolic compounds in three Malian medicinal plants and determines their antioxidant potential. Quantitative and qualitative analysis of polyphenolics contained in plants extracts were carried out by RP-C18 RP-HPLC using UV detector. The antioxidant activity was determined by three tests. They are phosphomolybdenum, DPPH (2,2-diphenyl1 picrylhydrazyl) and ABTS [2,2'-azino-bis(3-ethylbenzothiazoline-6-sulfonic)] tests. The total phenolic and the total flavonoid

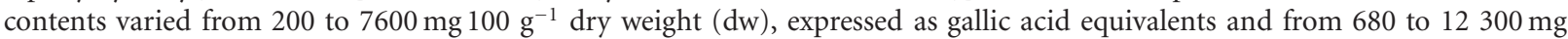
$100 \mathrm{~g}^{-1} \mathrm{dw}$ expressed as catechin equivalents, respectively. The total anthocyanin concentrations expressed as cyanin-3-glycoside

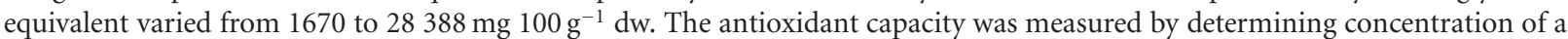
polyphenolic (in $\mathrm{mg} \mathrm{ml}^{-1}$ ) required to quench the free radicals by $50 \%\left(\mathrm{IC}_{50}\right.$ ) and expressed as vitamin $\mathrm{C}$ equivalent antioxidant capacity. The $\mathrm{IC}_{50}$ values were ranked between 2.68 and $8.80 \mu \mathrm{g} \mathrm{ml}^{-1}$ of a solution of $50 \%(\mathrm{v} / \mathrm{v})$ methanol in water. The uses of plants are rationalized on the basis of their antioxidant capacity.

\section{Introduction}

Several epidemiological studies suggest that plants rich in antioxidants play a protective role in health and against diseases [1], and their consumption lowered risk of cancer, heart disease, hypertension and stroke [2-4]. The major groups of phytochemicals that may contribute to the total antioxidant capacity of plant include polyphenols and vitamins ( $\mathrm{C}$ and E). Phenolic compounds can be nonnutrients [5]. Phenolic compounds of plants are hydroxylated derivatives of benzoic acid and cinnamic acids and have been reported to possess antioxidative and anticarcinogenic effects. Phenolic compounds including flavonoids are important in plant defense mechanisms against invading bacteria and other types of environmental stress $[5,6]$. Flavonoids have long been recognized to possess anti-inflammatory, anti-allergic, antiviral and antiproliferative activities [5-9]. Several reports indicate that the antioxidant potential of medicinal plants may be related to the concentration of their phenolic compounds which include phenolic acids, flavonoids, anthocyanins and tannins $[10,11]$. These compounds are of great value in preventing the onset and/or progression of many human diseases [12]. The health-promoting effect of antioxidants from plants is thought to arise from their protective effects by counteracting reactive oxygen species [11]. Antioxidants are compounds that help delay and inhibit lipid oxidation and when added to foods tend to minimize rancidity, retard the formation of toxic oxidation products, help maintain the nutritional quality and increase their shelf life [13].

We have recently reported the evaluation of the antioxidant potential of some medicinal and dietary plants [14, $15]$ and the positive correlation between peripheral blood granulocyte oxidative status and level of anxiety in mice [1517].

The objectives of this investigation are (i) to evaluate the level of total phenolics, flavonoids and anthocyanins in three sub-Saharian medicinal plants (Daniella oliveri, Ficus capensis and Vitex doniana) used for treating hypertension and considered as diuretic, anti-inflammatory, antipyretic and antipurulent agents (Table 1) and (ii) to evaluate total antioxidant potential by using vitamin $\mathrm{C}$ equivalent antioxidant capacity (VCEAC) tests. 
TABLE 1: Name, traditional uses and phytocomponents data.

\begin{tabular}{|c|c|c|c|c|}
\hline Plant name & Family & Uses & Pharmacology data & Phytocomponents data \\
\hline $\begin{array}{l}\text { Daniella oliveri } \\
\text { (D. thurifera) } \\
\text { Rolfe }\end{array}$ & Caesalpiniaceae & $\begin{array}{l}\text { Treatment diarrheic (leaves), } \\
\text { Bactericide, anti-inflammatory, } \\
\text { analgesic, antiseptic, } \\
\text { anti-diabetic, antispasmodic, } \\
\text { anti-haemorrhoid, aphrodisiac, } \\
\text { relaxing }\end{array}$ & $\begin{array}{l}\text { Analgesic (hexane extract), } \\
\text { antipyretic (ethyl acetate } \\
\text { extract), anti-inflammatory, } \\
\text { bactericide, anti-histamic } \\
\text { (methanol extract) [18-21] }\end{array}$ & $\begin{array}{l}\text { Polyphenols, flavonoids, } \\
\text { anthocyanins, glycosides, } \\
\text { tannins, saponins, terpenes, } \\
\text { alkaloids }\end{array}$ \\
\hline $\begin{array}{l}\text { Vitex doniana } \\
\text { (V. umbrosa) }\end{array}$ & Verbenaceae & $\begin{array}{l}\text { Bactericide (leaves and stems); } \\
\text { diuretic (leaves) tonifiant (roots); } \\
\text { aphrodisiac (leaves, roots) } \\
{[22,23] \text {; anti-diabetic (stems) }} \\
\text { antiseptic (leaves) }\end{array}$ & Bactericide (aqueous extract) & $\begin{array}{l}\text { Saponins, steroids, terpene, [24] } \\
\text { flavonoids, polyphenols, } \\
\text { vitamins C, A, E }\end{array}$ \\
\hline $\begin{array}{l}\text { Ficus capensis } \\
\text { (Thumb) } \\
\text { (Forssk) }\end{array}$ & Moraceace & $\begin{array}{l}\text { Bactericide, anti-diabetic, } \\
\text { diuretic, aphrodisiac (stems, } \\
\text { roots) }[20,25,26]\end{array}$ & $\begin{array}{l}\text { Anti-diabetic, diuretic (methanol } \\
\text { extract) }\end{array}$ & $\begin{array}{l}\text { Polyphenols, flavonoids, tannins, } \\
\text { vitamin C }\end{array}$ \\
\hline
\end{tabular}

\section{Methods}

2.1. Apparatus. The RP-HPLC analyses were performed with a Waters 600E pump coupled to a Waters $486 \mathrm{UV}$ visible tunable detector and equipped with a Alltech Intertsil ODS column (RP C18 column size $4.6 \mathrm{~mm} \times 150 \mathrm{~mm}$; particle size, $5 \mu \mathrm{m})$. In addition, spectrophotometer analyses were carried out with UV-Vis spectrophotometer (Cary 50 scan).

2.2. Chemicals. Folin-Ciocalteu's phenol reagent, aluminum chloride, catechin, gallic acid, $p$-coumaric acid, coumarin, rutin, protocatechic acid, vitamin acid, caffeic acid, isovitexin, chlorogenic acid, delphinidin, orientin, malvidin, homoorientin, ellagic acid, L-cyanidin, peonidin were purchased from Across Organics. Sodium carbonate, sodium nitrite, chlorhydric acid, ethyl acetate, sodium sulfate anhydrous, ammonium phosphate, ferric ammonium sulfate, acetonitrile, methanol, 2,2' -azino-bis(3-ethylbenzothiazoline-6-sulfonic) (ABTS), PBS buffer, AAPH [2,2'-azobis(2-amidino-propane)dihydrochloride; ABTS: 2,2'-azinobis(3-ethylbenzothiazoline-6-sulfonic)] and DPPH (2,2diphenyl-1 picrylhydrazyl) were obtained from Sigma and Roth (France). The chemicals used were all of analytical grade.

2.3. Procurement and Preparation of Samples. The plants $D$. oliveri, F. capensis and $V$. doniana were obtained from the Department of Traditional Medicine of Mali, upon arrival at the laboratory, different parts of the plants (leaves, root barks and stem barks) were dried at room temperature, powdered and sifted in a sieve $(0.750 \mu \mathrm{m})$. The plant material was biologically authenticated by the National Institute for Research in Public Health of Bamako.

\subsection{Samples Extractions}

2.4.1. Total Phenolic, Flavonoid, Anthocyanin Contents and Antioxidant Capacity. Samples for total phenolic compounds (TPC), total flavonoid compounds (TFC), total anthocyanin compounds (TAC) and total antioxidant capacity assays were extracted from the different powders as described by Makkard et al. [27] slightly modified. The powder sample $(2 \mathrm{~g})$ was extracted twice with $20 \mathrm{ml}$ of cold aqueous methanol solution (50\%). The two volumes were combined, made up to $40 \mathrm{ml}$, centrifuged at $1238 \mathrm{~g}$ for $20 \mathrm{~min}$ and transferred in small sample bottles and stored at $+4^{\circ} \mathrm{C}$ in the dark until analysis.

2.4.2. Extraction of Polyphenol Compounds for RP-HPLC Analysis. Polyphenols were extracted following the method described by Muchuweti et al. [28] slightly modified. Fresh samples $(5 \mathrm{~g})$ of plants portions were extracted twice with ethyl acetate $(20 \mathrm{ml})$ and organic fractions were combined. After 30 min of drying with anhydrous $\mathrm{NaSO}_{4}$, the extract was evaporated to dryness at $40^{\circ} \mathrm{C}$. Then, the residue was dissolved in methanol/water $[2 \mathrm{ml} 1: 1(\mathrm{v} / \mathrm{v})]$ before analysis by RP-HPLC. The standard solutions were prepared by dissolving $1 \mathrm{mg} \mathrm{ml}^{-1}(\mathrm{~m} / \mathrm{v})$.

\subsection{Dosage of Phenolic Compounds}

\subsubsection{Spectrophotometer Analysis}

Dosage of TPC. TPC were determined following Muchuweti et al. [28] method which was slightly modified. To a sample of $100 \mu \mathrm{l}$, distilled water was added to make the quantity $2 \mathrm{ml}$ (Eppendorff tube), followed by addition of $1 \mathrm{ml}$ of Folin-Ciocalteu reagent $(1 \mathrm{~N})$ and sodium carbonate $(20 \%)$. After $40 \mathrm{~min}$ at room temperature, absorbance at $725 \mathrm{~nm}$ was read on a spectrophotometer against a blank that contained methanol instead of sample. TPC were expressed in terms of equivalent amounts of gallic acid (GAE).

Determination of TFC. TFCs were measured according to a colorimetric assay slightly modified $[12,29]$. A $250 \mu \mathrm{l}$ of standard solution of catechin at different concentrations or appropriately diluted samples was added to $10 \mathrm{ml}$ volumetric flask containing $1 \mathrm{ml}$ of didistillate waters $\left(\mathrm{ddH}_{2} \mathrm{O}\right)$. At time $0 \mathrm{~min}, 75 \mu \mathrm{l}$ of $\mathrm{NaNO}_{2}(5 \%)$ was added to the flask. After $5 \mathrm{~min}, 75 \mu \mathrm{l}$ of $\mathrm{AlCl}_{3}(10 \%)$ was added. At $6 \mathrm{~min}, 500 \mu \mathrm{l}$ 
of $\mathrm{NaOH}(1 \mathrm{~N})$ was added to the mixture. Immediately,

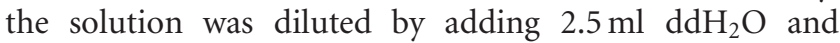
mixed thoroughly. Absorbance of the mixture, pink in color, was determined at $510 \mathrm{~nm}$ versus the prepared blank. TFCs in medicinal plants were expressed as microgramcatechin equivalents (CE)/gram dry weight (dw). Samples were analyzed in three replications.

Evaluation of TAC. The anthocyanin contents of samples was estimated by a UV-spectrophotometer with the $\mathrm{pH}$ differential method [30, 31] using two buffer systems, potassium chloride buffer, $\mathrm{pH} 1.0(0.025 \mathrm{M})$ and sodium acetate buffer, pH $4.5(0.4 \mathrm{M})$. Briefly, $400 \mu \mathrm{l}$ of extract was mixed in $3.6 \mathrm{ml}$ of corresponding buffer solutions and read against a blank at 510 and $700 \mathrm{~nm}$. Absorbance $(\Delta A)$ was calculated as: $\Delta A=\left(A_{510}-A_{700}\right) \mathrm{pH}_{1.0}-\left(A_{510}-A_{700}\right) \mathrm{pH}_{4.0}$ [30-32]. Monomeric anthocyanin pigment concentration in the extract was calculated and expressed as cyaniding -3 glycoside $\left(\mathrm{mgl}^{-1}\right): \Delta A \times \mathrm{MW} \times \mathrm{Df} \times 1000 /(\mathrm{Ma} \times 1) \quad[30$ 33] with $\triangle A$ : Absorbance, Mw: molecular weight (449.2), Ma: Molecular absorptivity (26.900) and Df: dilution factor.

2.5.2. RP-HPLC Analysis. RP-RP-HPLC analysis was performed according to the modified method describe [34, 35]. Extracted sample was filtered through a $0.45-\mu \mathrm{m}$ polytetrefluoroethylene syringe tip filter, using a $20-\mu 1$ sample loop. The sample was analyzed using an RP-HPLC system equipped with a waters UV-Visible tunable detector on a Reverse Phase (RP C18) column Alltech Intertsil ODS $-5 \mu \mathrm{m} \times 4.6 \mathrm{~mm} \times 150 \mathrm{~mm}$. The flow rate was set at $1 \mathrm{ml} \mathrm{min}-1$ at room temperature. A gradient of three mobile phases was used in the study, solvent A: $50 \mathrm{mM}$ ammonium phosphate $\left(\mathrm{NH}_{4} \mathrm{H}_{2} \mathrm{PO}_{4}\right) \mathrm{pH} 2.6$ (adjusted with phosphoric acid); solvent $\mathrm{B}$ : Which was constituted of $80: 20(\mathrm{v} / \mathrm{v})$ acetonitrile/solvent $\mathrm{A}$, and solvent $\mathrm{C}$, constituted of $200 \mathrm{mM}$ phosphoric acid $\mathrm{pH} 1.5$ ( $\mathrm{pH}$ adjusted with ammonium hydroxide). The solvents were filtered through a Whatman Maidstone England paper No. 3 and putted in an ultrasonic apparatus for $25 \mathrm{~min}$. The gradient profile was linearly change as follows (total $60 \mathrm{~min}$ ): $100 \%$ solvent A at $0 \mathrm{~min}, 92 \% \mathrm{~A} / 8 \% \mathrm{~B}$ at $4 \mathrm{~min}, 14 \% \mathrm{~B} / 86 \% \mathrm{C}$ at $10 \mathrm{~min}$, $16 \% \mathrm{~B} / 84 \% \mathrm{C}$ at $22.5 \mathrm{~min}, 25 \% \mathrm{~B} / 75 \% \mathrm{C}$ at $27.5 \mathrm{~min}$, $80 \% \mathrm{~B} / 20 \% \mathrm{C}$ at $50 \mathrm{~min}, 100 \% \mathrm{~A}$ at $55 \mathrm{~min}, 100 \% \mathrm{~A}$ at $60 \mathrm{~min}$ [36]. After each run, the system was reconditioned for $10 \mathrm{~min}$ before analysis of next sample. Under these conditions, $20 \mu \mathrm{l}$ of sample were injected. All sample analysis was done in triplicate. Polyphenolic standards prepared by dissolving $1 \mathrm{mg} \mathrm{ml}^{-1}$ were used to generate characteristic UV spectra and calibration curves. The individual polyphenolic compounds in the sample were identified by comparison of their UV-visible spectra and their retention times with the spike of the corresponding polyphenolic standards.

The detection was carried out at 280 and $320 \mathrm{~nm}$ and their quantification was obtained by the comparison of the peaks area with the corresponding standards calibration curves. Collected results were reported as equivalent amount of commercial standard.
2.6. Antioxidant Activity. Three different tests have been used to determine the total antioxidant capacity: the phosphomolybdenum (PPM) test, the ABTS test and the DPPH test $[37,38]$.

2.6.1. PPM Test. The PPM assay is a DPPH scavenging method in which, hydrogen and electron transfer from antioxidant analytes to DPPH and Molybdenum(VI) complex occur in the DPPH and PPM. The transfers occur at different redox potentials in the two assays and also depend on the structure of antioxidant. Several flavonoids and phenols have been isolated from plant parts with potent DPPH scavenging activities [39], whereas the PPM method usually detects antioxidants such as vitamins $\mathrm{C}, \mathrm{E}$ and some specific phenol [37]. In general, the extraction solvent affects the antioxidant capacity, the aqueous methanol extract showed better antioxidant activities than the organic extract, aqueous alcohol is considered to be the best solvent for the extraction of phenolic compounds from plant materials $[40,41]$.

The total antioxidant capacity of the plant extracts was measured by the method described by Prieto et al. [37]; $100 \mu \mathrm{l}$ of the sample solution was mixed with $900 \mu \mathrm{l}$ of the reagent solution $(0.6 \mathrm{M}$ sulfuric acid, $28 \mathrm{mM}$ sodium phosphate and $4 \mathrm{mM}$ ammonium molybdate) against a blank containing $100 \mu \mathrm{l}$ of methanol mixed with $900 \mu \mathrm{l}$ of reagent solution. The absorbance of the test sample was measured at $695 \mathrm{~nm}$. The antioxidant activity was expressed as vitamin C

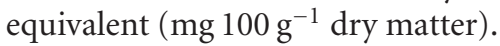

2.6.2. ABTS Test. The method used in this test is the one developed by Vanden Berg et al. [38], slightly modified. One millimolar of AAPH solution was mixed with $2.5 \mathrm{mM}$ ABTS as diammonium salt in phosphate buffered saline (PBS) solution $100 \mathrm{M}$ potassium phosphate buffered ( $\mathrm{pH} 7.4$ ) containing $150 \mathrm{mM} \mathrm{NaCl}$. The mixture was heated in a water bath at $68^{\circ} \mathrm{C}$ for $20 \mathrm{~min}$. The concentration of the resulting blue-green ABTS radical anion solution was adjusted to an absorbance of $0.65 \pm 0.02$ at $734 \mathrm{~nm}$. The sample solution $(60 \mu \mathrm{l})$ was added to $2.94 \mathrm{ml}$ of the resulting blue-green ABTS radical solution. The mixture, protected from light, was incubated in a water bath at $37^{\circ} \mathrm{C}$ for $20 \mathrm{~min}$. Then the decrease of absorbance was measured at $734 \mathrm{~nm}$. The control solution was consisted by $60 \mu \mathrm{l}$ of methanol and $2.94 \mathrm{ml}$ of ABTS radical anion solution. The stable ABTS radical anion scavenging activity of the plants phenolic compounds in the extracts was expressed as mg $100 \mathrm{~g}^{-1}$ dry plants powders and as $\mathrm{mg} 100 \mathrm{ml}^{-1}$ standards compounds of VCEAC in $20 \mathrm{~min}$. All radical stock solutions were prepared fresh daily.

\subsubsection{DPPH Test}

DPPH Evaluation. The antioxidant activity of plant extract was estimated using a slight modification of the DPPH radical scavenging protocol reported by Chen et al. [42]; $1 \mathrm{ml}$ of $100 \mu \mathrm{M}$ DPPH solution in methanol was mixed with $0.1 \mathrm{ml}$ of plant extract. The reaction mixture was incubated in the dark for $20 \mathrm{~min}$ and thereafter the optical density was recorded at $517 \mathrm{~nm}$ against the blank. 


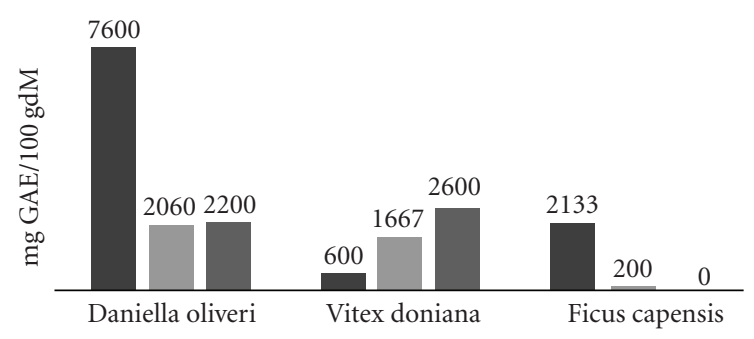

(a)

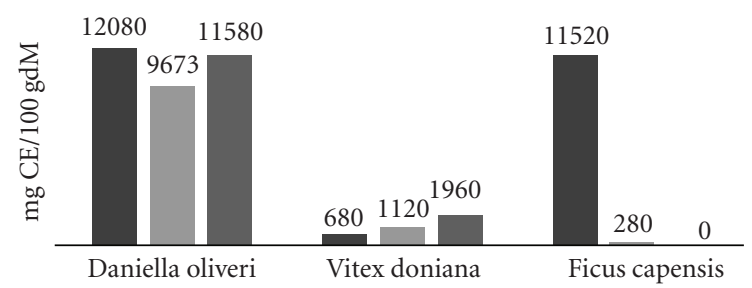

(b)

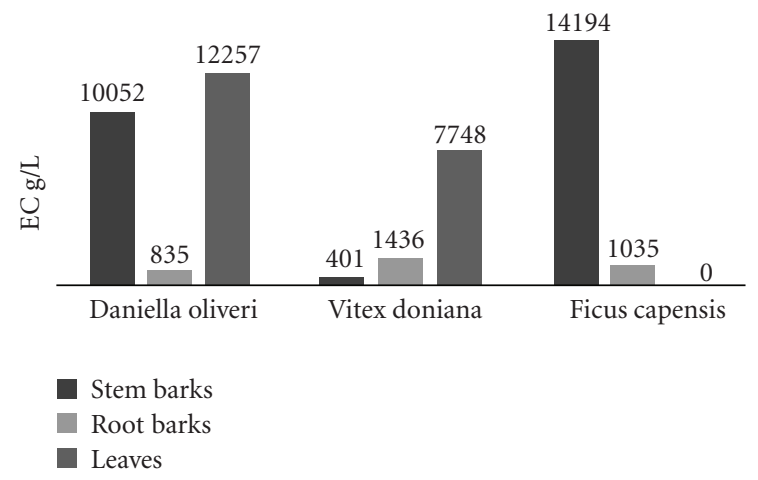

(c)

Figure 1: (a) Total polyphenols, (b) total flavonoids, (c) total anthocyanins.

For the control, $1 \mathrm{ml}$ of DPPH solution in methanol $(100 \mu \mathrm{M})$ was mixed with $0.1 \mathrm{ml}$ of methanol and optical density of the solution was recorded after $20 \mathrm{~min}$. The decrease in optical density of DPPH on addition of test samples in relation to the control was used to calculate the antioxidant activity as percentage of inhibition (\%IP) of DPPH radical, \%IP $=\left[\left(A t_{0}-A t_{20}\right) /\left(A t_{0} \times 1000\right)\right][12,43]$ where $A t_{0}$ : absorbance of the sample test after $0 \mathrm{~min}$ and $A t_{20}$ : absorbance of the control after $20 \mathrm{~min}$. Each assay was carried out in triplicate.

From a plot of concentration against \%IP, a linear regression analysis was performed to determine the $\mathrm{IC}_{50}$ value (concentration of a polyphenolic (in $\mathrm{mg} \mathrm{ml}^{-1}$ ) required to quench the free radicals by $50 \%$ ) for each plant extract. The $\mathrm{DPPH}$ radical scavenging activity of phenolic compounds was expressed as $\mathrm{IC}_{50}$ value in micrograms per milliliter of fresh weight. A low $\mathrm{IC}_{50}$ value represents a high antioxidant activity.

DPPH Determination. The DPPH scavenging activity was determined using a modified method of Kim et al. [35]. To $2.90 \mathrm{ml}$ of an aqueous methanol solution (50\%) of $100 \mu \mathrm{M}$ of
DPPH, $100 \mu \mathrm{l}$ of the plant extracts solution was added. The mixture was shaken and allowed to stand at $20^{\circ} \mathrm{C}$ in dark for $30 \mathrm{~min}$. After the decrease in absorbance, the resulting solution was monitored at $517 \mathrm{~nm}$. The DPPH radical scavenging activity of phenolic compounds was expressed as mg $100 \mathrm{~g}^{-1}$ of dry matter and as $\mathrm{mg} 100 \mathrm{ml}^{-1}$ of VCEAC in $30 \mathrm{~min}$. The control solution was consisted by $100 \mu \mathrm{l}$ of methanol and $2.90 \mathrm{ml}$ of DPPH solution. The radical solution was prepared daily.

2.7. Statistical Analysis. Results are presented as mean \pm standard error; statistical analysis of experimental result was based on analysis of variance. Significant difference was statistically considered at the level of $P<.001$.

\section{Results}

3.1. TPCs, TFCs and TACs. TPCs, TFCs and TACs were quantified using a UV-vis spectrophometric apparatus. The results of analysis are showed in Figure 1. No data were recorded for F. capensis leaves due to lack of sample.

3.2. RP-HPLC Analysis. Quantitative and qualitative comparison of polyphenolic compounds (TPC, TFC, TAC) were conducted using RP-HPLC.

The retention time of standards and their corresponding concentration in the samples were collected in Table 2. The experimentation has been done in four replicates. However, it is important to note that numerous peaks were not identified owing to the absence of suitable standards.

3.3. Antioxidant Activity. On the three plants screened, the extracts revealed good scavenging antioxidant activities as well as by PPM, ABTS or DPPH tests. The scavenging antioxidant activities of the different samples were reported in Table 3. Figure 2 showed the relationship between the antioxidant activities and the polyphenolic compounds (TPC, TFC, TAC) in the samples.

\section{Discussion}

The distribution of TPC in D. oliveri and V. doniana differs. The content of TPC are higher in leaves than in stem barks in $V$. doniana, whereas in D. oliveri TPC is more concentrated in the stem barks (Figure 1). The concentration of TFC is very low in the root barks of $F$. capensis. The stem bark extracts of $D$. oliveri and $F$. capensis contain almost the same levels of TFC. Daniella oliveri plant parts, stem barks, root barks and leaves exhibit a similar TFC (Figure 1). For all the three plants, the concentration of TAC is lowest in the root barks.

RP-HPLC analysis revealed that the caffeic acid in the stem barks of $D$. oliveri is the most important phenolic compound (2410.4 $\mu \mathrm{g} \mathrm{ml}^{-1}$ ), whereas its levels are too low in the other two plants ( $V$. doniana, $8.2 \mu \mathrm{g} \mathrm{ml}^{-1}$ and $F$. capensis, $\left.12.7 \mu \mathrm{g} \mathrm{ml}^{-1}\right)$. Moreover, it appears that rutin is in very high concentration $\left(6363.0 \mu \mathrm{g} \mathrm{ml}^{-1}\right)$ in the root barks of $V$. doniana and almost absent in the root barks of $D$. oliveri and F. capensis. 
TABLE 2: Compounds identified in the different plant parts and their concentration.

\begin{tabular}{|c|c|c|c|c|c|c|c|c|c|c|}
\hline \multirow{2}{*}{$\begin{array}{l}\text { Name of } \\
\text { compound }\end{array}$} & \multirow{2}{*}{ Family } & \multirow{2}{*}{$\begin{array}{l}\text { Retention } \\
\text { time } \\
(\mathrm{min})\end{array}$} & \multicolumn{3}{|c|}{ Stem barks $\left(\mu \mathrm{g} \mathrm{ml}^{-1}\right)$} & \multicolumn{3}{|c|}{ Root barks $\left(\mu \mathrm{g} \mathrm{ml}^{-1}\right)$} & \multicolumn{2}{|c|}{ Leaves $(\mu \mathrm{g} / \mathrm{ml})$} \\
\hline & & & $\begin{array}{c}D . \\
\text { oliveri }\end{array}$ & $\begin{array}{c}V . \\
\text { doniana }\end{array}$ & $\begin{array}{c}F . \\
\text { capensis }\end{array}$ & $\begin{array}{c}\text { D. } \\
\text { oliveri }\end{array}$ & $\begin{array}{c}V . \\
\text { doniana }\end{array}$ & $\begin{array}{c}F . \\
\text { capensis }\end{array}$ & $\begin{array}{c}\text { D. } \\
\text { oliveri }\end{array}$ & $\begin{array}{c}V \\
\text { doniana }\end{array}$ \\
\hline Gallic acid & $\mathrm{P}$ & 11.2 & $\begin{array}{c}210.1 \pm \\
1.5\end{array}$ & $\begin{array}{c}190.9 \pm \\
0.2\end{array}$ & $\begin{array}{c}1180 \pm \\
4\end{array}$ & $\begin{array}{c}1202 \pm \\
2\end{array}$ & $\begin{array}{c}168.6 \pm \\
0.4\end{array}$ & $\begin{array}{c}1.6 \pm \\
0.1\end{array}$ & $\begin{array}{c}292.5 \pm \\
0.3\end{array}$ & $\begin{array}{c}471.4 \pm \\
0.2\end{array}$ \\
\hline $\begin{array}{l}\text { Protocatechic } \\
\text { acid }\end{array}$ & $\mathrm{P}$ & 17.0 & $\begin{array}{c}19.8 \pm \\
0.2\end{array}$ & $\begin{array}{c}63.5 \pm \\
1.4\end{array}$ & $\begin{array}{c}71.6 \pm \\
0.3\end{array}$ & $\begin{array}{c}1.2 \pm \\
0.1\end{array}$ & $\begin{array}{c}22.7 \pm \\
0.1\end{array}$ & $\begin{array}{c}1.6 \pm \\
0.1\end{array}$ & $\begin{array}{c}0.8 \pm \\
0.1\end{array}$ & $\begin{array}{c}34.8 \pm \\
0.3\end{array}$ \\
\hline Catechin & $\mathrm{F}$ & 25.0 & ND & $\begin{array}{c}10.4 \pm \\
0.1\end{array}$ & $\begin{array}{c}3.0 \pm \\
0.1\end{array}$ & ND & $\begin{array}{c}51.5 \pm \\
0.2\end{array}$ & $\begin{array}{c}0.8 \pm \\
0.1\end{array}$ & $\begin{array}{c}4.1 \pm \\
0.1\end{array}$ & $\begin{array}{c}1.4 \pm \\
0.1\end{array}$ \\
\hline $\begin{array}{l}\text { Chlorogenic } \\
\text { acid }\end{array}$ & $\mathrm{P}$ & 26.5 & $\begin{array}{c}505.2 \pm \\
0.4\end{array}$ & $\begin{array}{c}4.2 \pm \\
0.1\end{array}$ & $\begin{array}{c}12.3 \pm \\
0.1\end{array}$ & ND & ND & $\begin{array}{c}0.6 \pm \\
0.1\end{array}$ & $\begin{array}{c}1.1 \pm \\
0.1\end{array}$ & $\begin{array}{c}1.7 \pm \\
0.1\end{array}$ \\
\hline Caffeic acid & $\mathrm{P}$ & 28.7 & $\begin{array}{c}2410.4 \\
\pm 12\end{array}$ & $\begin{array}{c}8.2 \pm \\
0.1\end{array}$ & $\begin{array}{c}12.7 \pm \\
0.1\end{array}$ & $\begin{array}{c}0.9 \pm \\
0.1\end{array}$ & ND & $\begin{array}{c}5.2 \pm \\
0.1\end{array}$ & $\begin{array}{c}13.6 \pm \\
0.2\end{array}$ & ND \\
\hline $\begin{array}{l}p \text {-Coumaric } \\
\text { acid }\end{array}$ & $\mathrm{P}$ & 33.5 & $\begin{array}{c}322.4 \pm \\
3.7\end{array}$ & $\begin{array}{c}9.2 \pm \\
0.1\end{array}$ & $\begin{array}{c}827.2 \pm \\
3.5\end{array}$ & $\begin{array}{c}127.6 \pm \\
2.1\end{array}$ & ND & $\begin{array}{c}827.2 \pm \\
0.8\end{array}$ & $\begin{array}{c}18.9 \pm \\
0.2\end{array}$ & $\begin{array}{c}18.8 \pm \\
0.3\end{array}$ \\
\hline $\begin{array}{l}\text { Homo- } \\
\text { orientin }\end{array}$ & $\mathrm{F}$ & 35.4 & $\begin{array}{c}784.4 \pm \\
4.9\end{array}$ & $\begin{array}{c}453.6 \pm \\
4.0\end{array}$ & $\begin{array}{c}36.6 \pm \\
0.1\end{array}$ & $\begin{array}{c}6.2 \pm \\
0.2\end{array}$ & $\begin{array}{c}2804 \pm \\
4\end{array}$ & $\begin{array}{c}194.9 \pm \\
0.3\end{array}$ & $\begin{array}{c}894.9 \pm \\
4.5\end{array}$ & $\begin{array}{c}384.1 \pm \\
2\end{array}$ \\
\hline Orientin & $\mathrm{F}$ & 36.4 & ND & $\begin{array}{c}3.8 \pm \\
0.1\end{array}$ & $\begin{array}{c}9.0 \pm \\
0.1\end{array}$ & $\begin{array}{c}1.0 \pm \\
0.1\end{array}$ & $\begin{array}{c}247.1 \pm \\
2.0\end{array}$ & $\begin{array}{c}9.0 \pm \\
0.1\end{array}$ & ND & $\begin{array}{c}1.0 \pm \\
0.2\end{array}$ \\
\hline Rutin & $\mathrm{F}$ & 37.1 & $\begin{array}{c}144.2 \pm \\
2.4\end{array}$ & $\begin{array}{c}34.9 \pm \\
0.2\end{array}$ & $\begin{array}{c}22.7 \pm \\
0.2\end{array}$ & $\begin{array}{c}1.0 \pm \\
0.1\end{array}$ & $\begin{array}{c}6363 \pm \\
2\end{array}$ & $\begin{array}{c}6.1 \pm \\
0.1\end{array}$ & ND & $\begin{array}{c}11943 \\
\pm 5\end{array}$ \\
\hline $\begin{array}{l}\text { Quercitrin- } \\
\text { glucosyl }\end{array}$ & $\mathrm{F}$ & 38.0 & $\begin{array}{c}224.1 \pm \\
0.7\end{array}$ & $\begin{array}{c}96.3 \pm \\
0.3\end{array}$ & ND & $\begin{array}{c}115.6 \pm \\
0.4\end{array}$ & $\begin{array}{c}18.1 \pm \\
0.1\end{array}$ & ND & $\begin{array}{c}12.3 \pm \\
0.2\end{array}$ & $12.6 \pm 1$ \\
\hline $\begin{array}{l}\text { Quercitrin } \\
\text { dehydrate }\end{array}$ & $\mathrm{F}$ & 39.3 & $\begin{array}{c}5.0 \pm \\
0.2\end{array}$ & $\begin{array}{c}78.7 \pm \\
0.2\end{array}$ & $\begin{array}{c}1.8 \pm \\
0.1\end{array}$ & $\begin{array}{c}22.4 \pm \\
0.1\end{array}$ & $\begin{array}{c}1346 \pm \\
1\end{array}$ & $\begin{array}{c}83.2 \pm \\
0.5\end{array}$ & ND & $\begin{array}{c}1.7 \pm \\
0.1\end{array}$ \\
\hline Coumarin & $\mathrm{P}$ & 40.4 & $\begin{array}{c}1.9 \pm \\
0.1\end{array}$ & $\begin{array}{c}2.5 \pm \\
0.1\end{array}$ & $\begin{array}{c}13.8 \pm \\
0.1\end{array}$ & $\begin{array}{c}4.9 \pm \\
0.1\end{array}$ & $\begin{array}{c}33.9 \pm \\
0.7\end{array}$ & $\begin{array}{c}2.9 \pm \\
0.1\end{array}$ & $\begin{array}{c}29.2 \pm \\
0.4\end{array}$ & $\begin{array}{c}10.9 \pm \\
0.1\end{array}$ \\
\hline Malvidin & A & 42.0 & ND & $\begin{array}{c}39.1 \pm \\
0.2\end{array}$ & ND & ND & $\begin{array}{c}110.0 \pm \\
0.6\end{array}$ & ND & ND & $\begin{array}{c}8.3 \pm \\
0.1\end{array}$ \\
\hline Delphinidin & A & 42.5 & $\begin{array}{c}1.1 \pm \\
0.1\end{array}$ & $\begin{array}{c}35.3 \pm \\
0.1\end{array}$ & $\begin{array}{c}34.4 \pm \\
0.1\end{array}$ & ND & ND & $\begin{array}{c}7.6 \pm \\
0.1\end{array}$ & ND & ND \\
\hline Quercitrin & $\mathrm{F}$ & 44.0 & $\begin{array}{c}1.0 \pm \\
0.1\end{array}$ & ND & $\begin{array}{c}109.5 \pm \\
1.0\end{array}$ & $\begin{array}{c}5.0 \pm \\
0.1\end{array}$ & $\begin{array}{c}323.2 \pm \\
0.1\end{array}$ & $\begin{array}{c}63.3 \pm \\
0.2\end{array}$ & ND & $\begin{array}{c}1831 \pm \\
18\end{array}$ \\
\hline Ascorbic acid & Vit. C & 56.5 & $\begin{array}{c}2.5 \pm \\
0.1\end{array}$ & $\begin{array}{c}1.6 \pm \\
0.1\end{array}$ & $\begin{array}{c}14.5 \pm \\
0.4\end{array}$ & $\begin{array}{c}4.0 \pm \\
0.1\end{array}$ & $\mathrm{ND}$ & $\begin{array}{c}1.3 \pm \\
0.1\end{array}$ & ND & ND \\
\hline
\end{tabular}

ND: not determinate; A: Anthocyanidins; F: Flavonoids; P: Polyphenol. Data were reported as mean \pm SEM $(n=4)$.

TABLE 3: Antioxidant activity in vitro analysis.

\begin{tabular}{|c|c|c|c|c|c|c|}
\hline \multirow{2}{*}{ Plants } & \multirow{2}{*}{ Parts } & \multirow{2}{*}{$\begin{array}{l}\text { Test PPM } \\
\left(\mathrm{mg} 100 \mathrm{~g}^{-1} \mathrm{dw}\right)\end{array}$} & \multirow{2}{*}{$\begin{array}{l}\text { Test ABTS } \\
\left(\mathrm{mg} 100 \mathrm{~g}^{-1} \mathrm{dw}\right)\end{array}$} & \multicolumn{3}{|c|}{ Test DPPH } \\
\hline & & & & $\begin{array}{c}\text { VCEAC } \\
\left(\mathrm{mg} 100 \mathrm{~g}^{-1} \mathrm{dw}\right)\end{array}$ & $\%$ IP & $\begin{array}{c}\mathrm{IC}_{50} \\
\left(\mu \mathrm{g} \mathrm{ml}^{-1}\right)\end{array}$ \\
\hline \multirow[t]{3}{*}{$\begin{array}{l}\text { Daniella } \\
\text { oliveri }\end{array}$} & Stem barks & $586 \pm 12$ & $127.5 \pm 0.1$ & $193.7 \pm 1.8$ & $86.1 \pm 1.4$ & $2.9 \pm 0.1$ \\
\hline & Root barks & $606 \pm 1$ & $124.1 \pm 0.9$ & $196.3 \pm 0.7$ & $87.6 \pm 0.3$ & $2.8 \pm 0.1$ \\
\hline & Leaves & $526 \pm 4$ & $109.2 \pm 3.8$ & $210.3 \pm 0.4$ & $93.3 \pm 0.2$ & $2.7 \pm 0.1$ \\
\hline \multirow[t]{3}{*}{$\begin{array}{l}\text { Vitex } \\
\text { doniana }\end{array}$} & Stem barks & $74 \pm 6$ & $129.6 \pm 0.1$ & $205.5 \pm 2.3$ & $84.9 \pm 1.3$ & $2.9 \pm 0.1$ \\
\hline & Root barks & $194 \pm 7$ & $126.2 \pm 0.9$ & $200.1 \pm 1.1$ & $87.7 \pm 0.1$ & $2.8 \pm 0.1$ \\
\hline & Leaves & $180 \pm 5$ & $127.1 \pm 0.1$ & $195.0 \pm 1.3$ & $84.9 \pm 0.7$ & $2.9 \pm 0.1$ \\
\hline \multirow[t]{2}{*}{$\begin{array}{l}\text { Ficus } \\
\text { capensis }\end{array}$} & Stem barks & $280 \pm 3$ & $120.8 \pm 6.1$ & $195.8 \pm 3.3$ & $85.40 \pm 1.80$ & $2.9 \pm 0.1$ \\
\hline & Root barks & $60 \pm 2$ & $122.5 \pm 1.4$ & $91.3 \pm 0.5$ & $28.41 \pm 0.23$ & $8.8 \pm 0.1$ \\
\hline
\end{tabular}




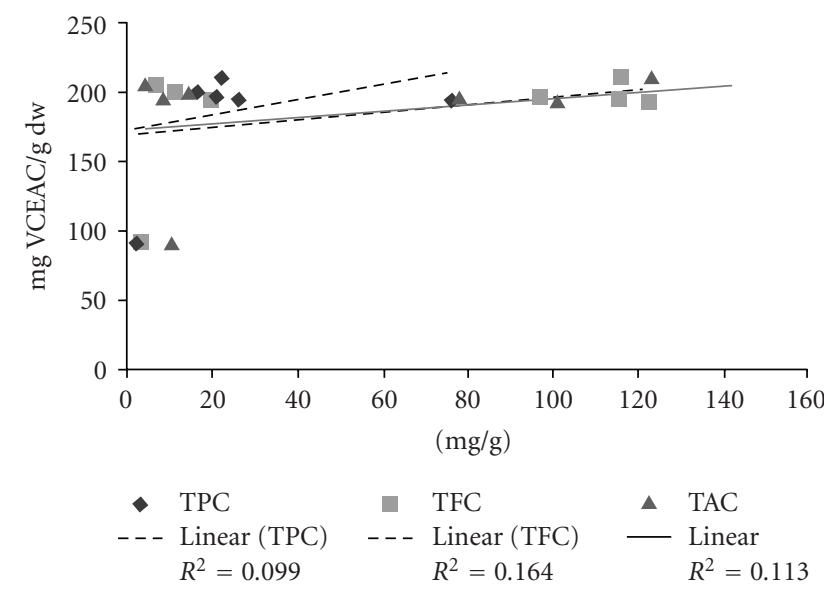

FIGURE 2: Relationship between the antioxidant activities and the polyphenolic compounds TPC (Total Phenolic Compounds); TFC (Total Flavonoid compounds) and TAC (Total Anthocyanin Compounds).

Rutin is the most important phenolic compound $\left(11943.0 \mu \mathrm{g} \mathrm{ml}^{-1}\right)$ in the leaves of $V$. doniana, while it is not detected in the leaves of D. oliveri (Table 2).

Antioxidant activity has been evaluated by three tests: PPM, ABTS and DPPH. The PPM assay showed that the highest value was $606.0 \mathrm{mg} 100 \mathrm{~g}^{-1} \mathrm{dw}$ (VCEAC) for the root barks of $D$. oliveri; in contrast, the lowest one was $60.0 \mathrm{mg} 100 \mathrm{~g}^{-1} \mathrm{dw}$ for the root barks of F. capensis (Table 3). The great variations observed between the different plants and plant parts could be explained by the fact that PPM essay evaluates the antioxidant activity of polyphenols, and others antioxidant agents which are not phenolic compounds [43]. To be more accurate about phenolic compounds, ABTS and DPPH tests have been done. ABTS tests showed that the antioxidant activity of different plants was almost the same. DPPH tests expressed as VCEAC varied from $91.3 \mathrm{mg}$ $100 \mathrm{~g}^{-1} \mathrm{dw}$ for the root barks of F. capensis to $205.5 \mathrm{mg}$ $100 \mathrm{~g}^{-1} \mathrm{dw}$ for the stem barks of $V$. doniana. In addition, the antioxidant activity evaluated as \%IP revealed a similar behavior. The highest IP value was $93.3 \%$ for the stem barks of $V$. doniana and the lowest one was $28.4 \%$ for the root barks of F. capensis. The \%IP and IC50 $\left(\mu \mathrm{g} \mathrm{ml}^{-1}\right)$ have been calculated to compare the antioxidant capacity of the studied plant parts extracts with those described by other authors in literature such as Adesegun et al. [44] and Ruchi et al. [43]. \%IP values were relatively high (28.41-93.3\%) and IC $_{50}$ relatively weak $\left(2.7-8.8 \mu \mathrm{g} \mathrm{ml}^{-1}\right)$. This revealed that these three Malian plants have very good antioxidant activities. Each plant contains generally different phenolic compounds with different amount of antioxidant activity.

Many studies indicate linear relationship between total phenolics and antioxidant activity $[10,12,45]$. In this study we found that polyphenolic compounds were not major contributors to antioxidant activity, since for TPCs, TFCs and TACs versus antioxidant activity, the correlation coefficients $R^{2}=0.0998,0.1641,0.1135$, respectively, were weak (Figure 2). These correlations have been established using all plant parts (stem barks, root barks, leaves). In conclusion, our results suggest that these plants are strong radical scavengers and can be seen as potential source of natural antioxidants for medicinal and commercial uses.

\section{Funding}

Ministry of Scientific Research of the Republic Democratic of Congo grant (No. 132.49/060/KMB/07).

\section{Acknowledgments}

Mr Frédéric Desort (Ethnobotanique et Pharmacologie, Anxiété, Stress oxydant et Bioactivité. Université P. VerlaineMetz, Metz, France) is acknowledged for technical assistance.

\section{References}

[1] J. A. Milner, "Functional foods and health promotion," Journal of Nutrition, vol. 129, no. 7, 1999.

[2] M. N. Diaz, B. Frei, J. A. Vita, and J. F. Keaney Jr., "Antioxidants and atherosclerotic heart disease," The New England Journal of Medicine, vol. 337, no. 6, pp. 408-416, 1997.

[3] J. A. Vinson, X. Su, L. Zubik, and P. Bose, "Phenol antioxidant quantity and quality in foods: fruits," Journal of Agricultural and Food Chemistry, vol. 49, no. 11, pp. 5315-5321, 2001.

[4] K. Wolfe, X. Wu, and R. H. Liu, "Antioxidant activity of apple peels," Journal of Agricultural and Food Chemistry, vol. 51, no. 3, pp. 609-614, 2003.

[5] A. R. Ndhlala, A. Kasiyamhuru, C. Mupure, K. Chitindingu, M. A. Benhura, and M. Muchuweti, "Phenolic composition of Flacourtia indica, Opuntia megacantha and Sclerocarya birrea," Food Chemistry, vol. 103, no. 1, pp. 82-87, 2007.

[6] G. Wallace and S. C. Fry, "Phenolic components of the plant cell wall," International Review of Cytology, vol. 151, pp. 229267, 1994.

[7] E. N. Frankel, J. Kanner, J. B. German, E. Parks, and J. E. Kinsella, "Inhibition of oxidation of human low-density lipoprotein by phenolic substances in red wine," The Lancet, vol. 341, no. 8843, pp. 454-457, 1993.

[8] T. Kuda, M. Tsunekawa, H. Goto, and Y. Araki, "Antioxidant properties of four edible algae harvested in the Noto Peninsula, Japan," Journal of Food Composition and Analysis, vol. 18, no. 7, pp. 625-633, 2005.

[9] S. Sharma, J. D. Stutzman, G. J. Kelloff, and V. E. Steele, "Screening of potential chemopreventive agents using biochemical markers of carcinogenesis," Cancer Research, vol. 54, no. 22, pp. 5848-5855, 1994.

[10] A. Djeridane, M. Yousfi, B. Nadjemi, D. Boutassouna, P. Stocker, and N. Vidal, "Antioxidant activity of some algerian medicinal plants extracts containing phenolic compounds," Food Chemistry, vol. 97, no. 4, pp. 654-660, 2006.

[11] C.-C. Wong, H.-B. Li, K.-W. Cheng, and F. Chen, "A systematic survey of antioxidant activity of 30 Chinese medicinal plants using the ferric reducing antioxidant power assay," Food Chemistry, vol. 97, no. 4, pp. 705-711, 2006.

[12] D.-O. Kim, O. K. Chun, Y. J. Kim, H.-Y. Moon, and C. Y. Lee, "Quantification of polyphenolics and their antioxidant capacity in fresh plums," Journal of Agricultural and Food Chemistry, vol. 51, no. 22, pp. 6509-6515, 2003.

[13] L. R. Fukumoto and G. Mazza, "Assessing antioxidant and prooxidant activities of phenolic compounds," Journal of 
Agricultural and Food Chemistry, vol. 48, no. 8, pp. 3597-3604, 2000.

[14] J. Bouayed, K. Piri, H. Rammal et al., "Comparative evaluation of the antioxidant potential of some Iranian medicinal plants," Food Chemistry, vol. 104, no. 1, pp. 364-368, 2007.

[15] J. Bouayed, A. Djilani, H. Rammal, A. Dicko, C. Younos, and R. Soulimani, "Quantitative evaluation of the antioxidant properties of Catha edulis," Journal of Life Sciences, vol. 2, pp. 7-14, 2008.

[16] J. Bouayed, H. Rammal, A. Dicko, C. Younos, and R. Soulimani, "Chlorogenic acid, a polyphenol from Prunus domestica (Mirabelle), with coupled anxiolytic and antioxidant effects," Journal of the Neurological Sciences, vol. 262, no. 1-2, pp. 7784, 2007.

[17] J. Bouayed, H. Rammal, C. Younos, and R. Soulimani, "Positive correlation between peripheral blood granulocyte oxidative status and level of anxiety in mice," European Journal of Pharmacology, vol. 564, no. 1-3, pp. 146-149, 2007.

[18] A. Ahmadu, A. K. Haruna, M. Garba, J. O. Ehinmidu, and S. D. Sarker, "Phytochemical and antimicrobial activities of the Daniellia oliveri leaves," Fitoterapia, vol. 75, no. 7-8, pp. 729732, 2004.

[19] E. A. Balogun and J. Adebayo, "Effect of ethanolic extract of Daniella oliveri leaves on some cardiovascular indices in rats," Pharmacognosy Magazine, vol. 4, pp. 16-20, 2008.

[20] A. M. El-Mahmood, J. H. Doughari, and F. J. Chanji, “In vitro antibacterial activities of crude extracts of Nauclea latifolia and Daniella oliveri," Scientific Research and Essays, vol. 3, no. 3, pp. 102-105, 2008.

[21] N. D. Onwukaeme, T. Y. Lot, and F. V. Udoh, "Effects of Daniellia oliveri stem bark and leaf extracts on rat skeletal muscle," Phytotherapy Research, vol. 13, no. 5, pp. 419-421, 1999.

[22] F. Ouattara, Traitement traditionnelle des infections sexuellement transmissibles au Mali: etude de la phytochimie et des activités biologiques des Annona senegalesis L. (Annonaceae) et de stochytarpheta augustifolia Valh (Verbenaceae), Thèse de doctorat, Université de Bamako, 2005.

[23] P. Goetz, "Traitement des troubles de la libido masculine," Phytothérapie Clinique, vol. 1, pp. 9-14, 2006.

[24] J. P. Higham, C. Ross, Y. Warren, M. Heistermann, and A. M. MacLarnon, "Reduced reproductive function in wild baboons (Papio hamadryas anubis) related to natural consumption of the African black plum (Vitex doniana)," Hormones and Behavior, vol. 52, no. 3, pp. 384-390, 2007.

[25] N. M. Baldé, A. Youla, M. D. Balde et al., "Herbal medicine and treatment of diabetes in Africa an example from Guinea," Diabetes \& Metabolism, vol. 32, no. 2, pp. 171-175, 2007.

[26] A. G. Peter and M. Desmet, "Traditional pharmacognosy and medicine in Africa ethnopharmacological in sub-saharan art objet and utensils," Journal of Ethnopharmacology, vol. 63, pp. 1-175, 1999.

[27] H. P. S. Makkar, Quantification of Tannins in Tree Foliage: A Laboratory Manual for the FAO/IAEA Co-ordinate Research Project on Use of Nuclear and Related Techniques to Develop Simple Tannin Assay for Predicting and Improving the Safety and Efficiency of Feeding Ruminants on the Tanniniferous Tree Foliage, Joint FAO/IAEA Division of nuclear techniques in Food and Agriculture, Vienna, Austria, 1999.

[28] M. Muchuweti, A. R. Ndhlala, and A. Kasiamhuru, "Analysis of phenolic compounds including tannins, gallotannins and flavanols of Uapaca kirkiana fruit," Food Chemistry, vol. 94, no. 3, pp. 415-419, 2006.
[29] J. Zhishen, T. Mengcheng, and W. Jianming, "The determination of flavonoid contents in mulberry and their scavenging effects on superoxide radicals," Food Chemistry, vol. 64, no. 4, pp. 555-559, 1999.

[30] S. Sellappan, C. C. Akoh, and G. Krewer, "Phenolic compounds and antioxidant capacity of Georgia-grown blueberries and blackberries," Journal of Agricultural and Food Chemistry, vol. 50, no. 8, pp. 2432-2438, 2002.

[31] S. Sellappan and C. C. Akoh, "Flavonoids and antioxidant capacity of Georgia-grown Vidalia onions," Journal of Agricultural and Food Chemistry, vol. 50, no. 19, pp. 5338-5342, 2002.

[32] J. Lako, V. C. Trenerry, M. Wahlqvist, N. Wattanapenpaiboon, S. Sotheeswaran, and R. Premier, "Phytochemical flavonols, carotenoids and the antioxidant properties of a wide selection of Fijian fruit, vegetables and other readily available foods," Food Chemistry, vol. 101, no. 4, pp. 1727-1741, 2007.

[33] R. L. Prior and G. Cao, "Antioxidant phytochemicals in fruits and vegetables: diet and health implications," HortScience, vol. 35, no. 4, pp. 588-592, 2000.

[34] M. B. Arnao, A. Cano, and M. Acosta, "The hydrophilic and lipophilic contribution to total antioxidant activity," Food Chemistry, vol. 73, no. 2, pp. 239-244, 2001.

[35] D.-O. Kim, K. W. Lee, H. J. Lee, and C. Y. Lee, "Vitamin C equivalent antioxidant capacity (VCEAC) of phenolic phytochemicals," Journal of Agricultural and Food Chemistry, vol. 50, no. 13, pp. 3713-3717, 2002.

[36] J. L. Donovan, A. S. Meyer, and A. L. Waterhouse, "Phenolic Composition and Antioxidant of prunes and prunes juice (Prunus domestica)," Journal of Agricultural and Food Chemistry, vol. 46, no. 4, pp. 1247-1252, 1998.

[37] P. Prieto, M. Pineda, and M. Aguilar, "Spectrophotometric quantitation of antioxidant capacity through the formation of a phosphomolybdenum complex: specific application to the determination of vitamin E," Analytical Biochemistry, vol. 269, no. 2, pp. 337-341, 1999.

[38] R. Van den Berg, G. R. M. M. Haenen, H. Van den Berg, and A. Bast, "Applicability of an improved Trolox equivalent antioxidant capacity (TEAC) assay for evaluation of antioxidant capacity measurements of mixtures," Food Chemistry, vol. 66, no. 4, pp. 511-517, 1999.

[39] S. K. Lee, Z. H. Mbwambo, H. Chung et al., "Evaluation of the antioxidant potential of natural products," Combinatorial Chemistry and High Throughput Screening, vol. 1, no. 1, pp. 35-46, 1998.

[40] M. Antolovich, P. Prenzler, K. Robards, and D. Ryan, "Sample preparation in the determination of phenolic compounds in fruits," Analyst, vol. 125, no. 5, pp. 989-1009, 2000.

[41] P. S. Negi, G. K. Jayaprakasha, and B. S. Jena, "Antioxidant and antimutagenic activities of pomegranate peel extracts," Food Chemistry, vol. 80, no. 3, pp. 393-397, 2003.

[42] Y. Chen, M. Wang, R. T. Rosen, and C.-T. Ho, "2,2-diphenyl1-picrylhydrazyl radical-scavenging active components from Polygonum multiflorum Thunb," Journal of Agricultural and Food Chemistry, vol. 47, no. 6, pp. 2226-2228, 1999.

[43] R. G. Marwah, M. O. Fatope, R. A. Mahrooqi, G. B. Varma, H. A. Abadi, and S. K. S. Al-Burtamani, "Antioxidant capacity of some edible and wound healing plants in Oman," Food Chemistry, vol. 101, no. 2, pp. 465-470, 2007.

[44] S. A. Adesegun, A. Fajana, C. I. Orabueze, and H. A. B. Coker, "Evaluation of antioxidant properties of phaulopsis fascisepala C.B.Cl. (Acanthaceae)," Evidence-Based Complementary and Alternative Medicine, vol. 6, no. 2, pp. 227-231, 2009. 
[45] R. Van den Berg, G. R. M. M. Haenen, H. Van den Berg, W. Van der Vijgh, and A. Bast, "The predictive value of the antioxidant capacity of structurally related flavonoids using the Trolox equivalent antioxidant capacity (TEAC) assay," Food Chemistry, vol. 70, no. 3, pp. 391-395, 2000. 


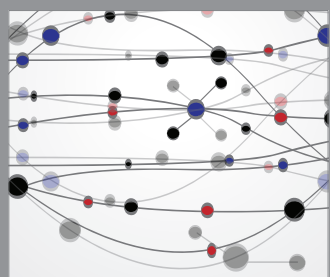

The Scientific World Journal
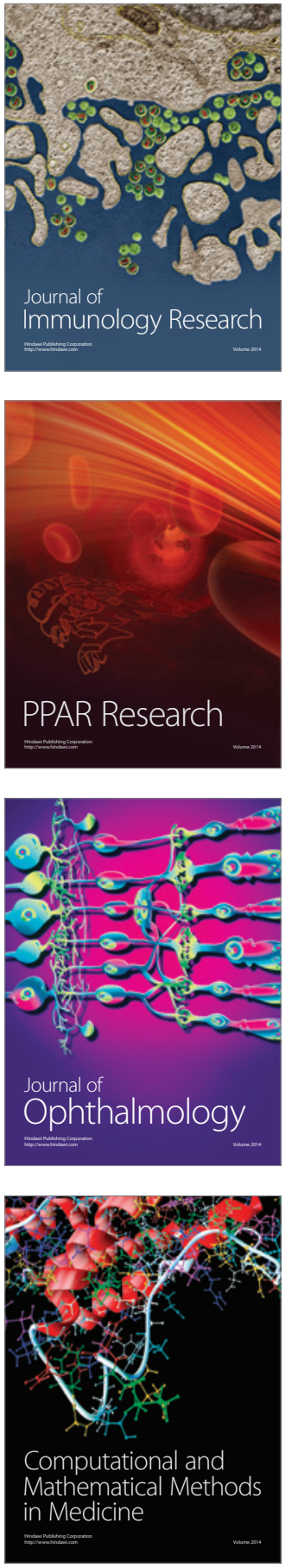

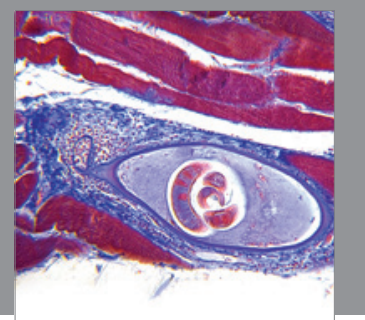

Gastroenterology

Research and Practice
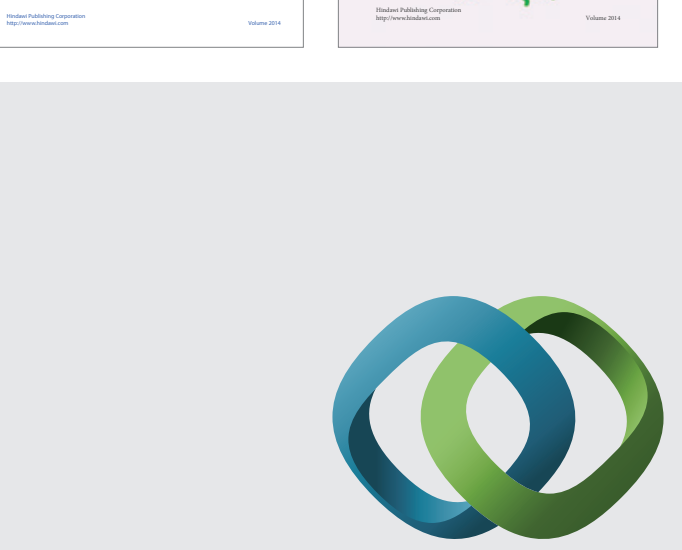

\section{Hindawi}

Submit your manuscripts at

http://www.hindawi.com
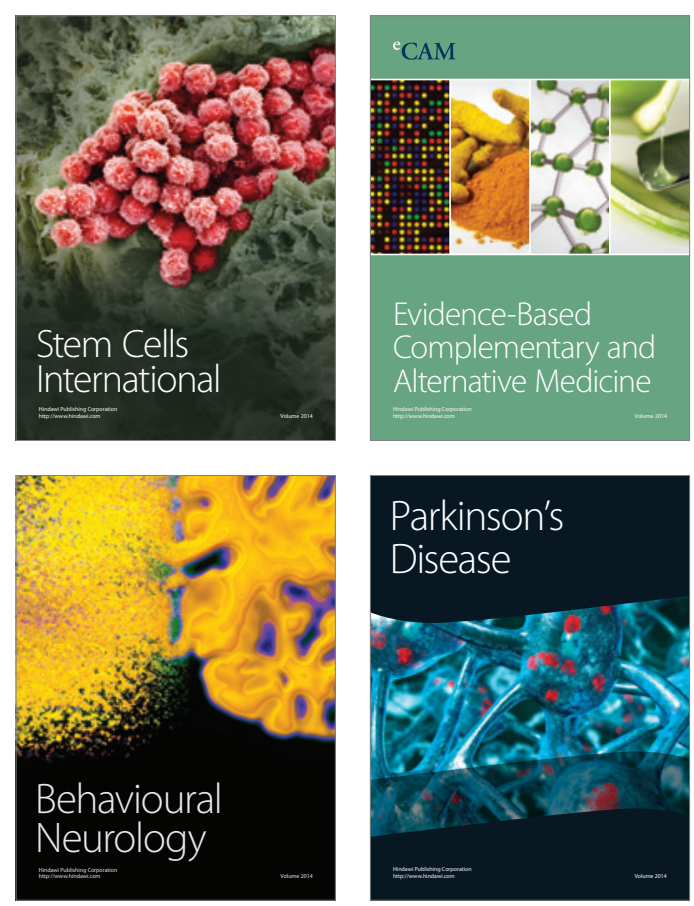

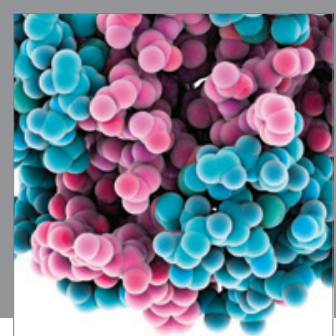

Journal of
Diabetes Research

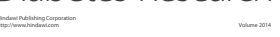

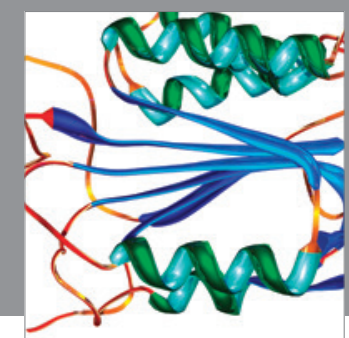

Disease Markers
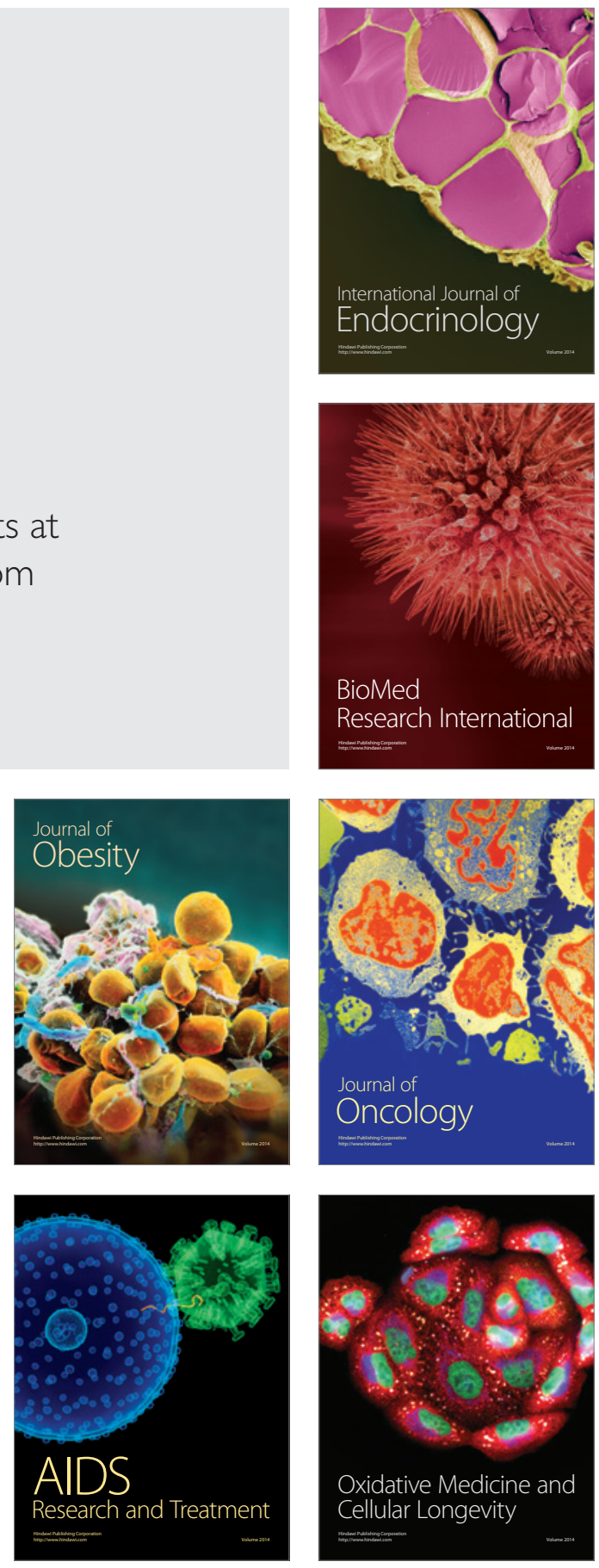